\title{
GUBERNUR JENDERAL VOC JAN PIETERSZOON COEN DAN PEMBANGUN KOTA BATAVIA (1619-1629)
}

\author{
Rani Noviyanti \\ Program Studi Pendidikan Sejarah, FIPPS \\ Universitas Indraprasta PGRI \\ Email: rasyaraninew @ gmail.com
}

\begin{abstract}
ABSTRACK
The establishment of the city of Batavia in the west of the northern coast of Java, is inseparable from the role of a character named Jean Pieterzoon Coen. Despite earlier Jayakarta (name before Batavia), controlled and built by Prince Fatahillah, but the circumstances in the field of social and economic Jayakarta unlike in the time management J.P. Coen. After Jayakarta controlled by the Company, through a policy of military expeditions designed by JP. Coen, the state of the town of Jayakarta slowly for the sake of gradually increasing the social and economic fields. The increase in the city of Batavia in the field of social and economic policies backed by three JP. Coen was brave enough, namely to increase trading activity in the port of Sunda Kalapa, revitalize the position of the islands in the north of Batavia as a base Adiministrasi and defense and security, as well as opening the door as possible for traders and ethnic Chinese settlers. Three of the policy, is actually pure thought-out meurpakan poured olh JP. Coen, after taking over control of the territory from the Jayakarta Prince Fatahillah.
\end{abstract}

Keyword: J.P. Coen, Kota Batavia.

\section{ABSTRAK}

Pendirian kota Batavia di sebelah barat pesisir pantai utara Jawa, tidak dapat dipisahkan dari peran seorang tokoh yang bernama Jean Pieterzoon Coen. Meskipun sebelumnya Jayakarta (nama sebelum Batavia), dikuasai dan dibangun oleh Pangeran Fatahillah, akan tetapi situasi dan kondisi dalam bidang sosial dan ekonomi Jayakarta tidak seperti pada masa pengelolaan J.P. Coen. Setelah Jayakarta dikuasai oleh VOC, melalui kebijakan ekspedisi militer yang dirancang oleh JP. Coen, keadaan kota Jayakarta perlahan demi perlahan semakin meningkat dalam bidang sosial dan ekonomi. Peningkatan kota Batavia dalam lapangan sosial dan ekonomi dilatari oleh tiga kebijakan JP. Coen yang cukup berani, yakni meningkatkan aktivitas perdagangan di pelabuhan Sunda Kalapa, merevitalisasi kedudukan pulau-pulau di utara Batavia sebagai basis adiministrasi dan pertahanan dan keamanan, serta membuka pintu seluas-luasnya bagi pedagang dan pendatang etnis Tionghoa. Tiga kebijakan tersebut, sejatinya meurpakan murni hasil pemikiran yang dituangkan olh JP. Coen, setelah mengambil alih wilayah Jayakarta dari penguasaan pangeran Fatahillah.

Kata Kunci : J.P. Coen, Kota Batavia. 


\section{PENDAHULUAN}

Berdirinya Batavia tidak terlepas dari sejarah munculnya pelabuhan Sunda Kalapa. Pelabuhan Sunda Kalapa merupakan pelabuhan kerajaan Sunda atau kerajaan Pajajaran. Menurut berita Tome Pires Pelabuhan Sunda Kalapa adalah pelabuhan yang sangat penting di Jawa Barat. Karena merupakan tempat berlabuh dan singgang pedagang-pedagang dari Palembang, Malaka, Sulawesi Selatan, Jawa, Madura, dan lain-lainya (Lubis dkk., 2003:83).

Pada tanggal 21 Agustus 1522 diadakanlah perjanjian persahabatan antara Kerajaan Pajajaran dan orang-orang Portugis. Isinya perjanjian adalah orang-orang Portugis boleh mendirikan benteng di pelabuhan Sunda Kalapa dan Kerajaan Pajajaran akan menerima barangbarang atau bahan-bahan yang dibutuhkannya. Persahabatan antara Portugis dan Kerajaan Pajajaran merupakan ancaman bagi Kesultanan Demak. Seperti yang diketahui Kerajaan Pajajaran adalah Kerajaan Hindu. Dan Portugis adalah Khatolik sedangkan dalam pelayaran dunia, Portugis membawa misi Gold, Glory, Gospel. Dimana Gospel adalah penyebaran agama Khatolik. Ini adalah ancaman bagi Kesultanan Demak, karena Kerajaan Demak juga memiliki misi menyebarkan Islam di Banten dan Cirebon.

Pada masa Kesultanan Demak Sultan Trenggono, beliau mengutus Fatahilah atau nama lainnya adalah Falatehan untuk merebut pelabuhan Sunda Kalapa. Sebelum benteng Portugis didirikan, Fatahillah dan kaum muslimin sudah dapat merebut pelabuhan Sunda Kalapa. Sunda Kalapa berganti nama menjadi Jayakarta atau kota kemenangan. Menurut Prof. Dr. Soekanto peristiwa itu terjadi pada tanggal 22 juni 1527. Sehingga hingga sekarang peringatan lahirnya kota Jakarta tetap diperingati pada tanggal 22 Juni 1527 (Soekanto, 1954:12).

Fatahillah sendiri tidak memimpin Jayakarta secara langsung tetapi diserahkan ke Tubagus Angke. Kemudian dari Tubagus Angke pemerintahan atas kabupatian Jayakarta atau Jakrata diserakan kepada puteranya bernama Pangeran Jayakarta Wijayakrama. Pada waktu orang-orang Belanda datang, Jayakarta atau Jakarta masuk dalam wilayah Karajaan Banten. Hal ini diperkuat oleh berita bahwa Pangeran Jayakarta membawa persembahan upeti ketika berkunjung ke Banten. Jakarta sudah sejak lama diincar oleh VOC. Karena letaknya yang strategis di Selat Sunda dan tidak begitu jauh dari Selat Malaka. VOC memang sudah memiliki kantor dagang di Banten tetapi kedudukan Kesulatanan Banten pada saat itu masih saat kuat makanya VOC menjatuhkan pilihan di Jayakarta atau Jakarta karena letaknya yang dekat dengan muara Sungai Ciliwung. VOC berkeinginan untuk mendirikan kantor dagang di Jayakarta atau Jakarta, tetapi izin ini ditolak. Akan tetapi diamdiam VOC dengan cara licik membuat gudang yang kokoh dan dan kuat yang dapat dijadikan loji atau benteng. Kedua loji tersebut dinamakan Nassau dan Mauritius (Sagimun, 1988: 63). Karena tidak minta izin atau persetujuan dari penguasa dari Jayakarta maka hubungan antara orang-orang Belanda dan pangeran Jayakarta Wijayakrama menjadi renggang. Pada saat itu, datanglah armada Inggris.

Pangeran Jayakarta Wijayakrama dibantu orangorang Inggris sedangkan Jan Pieterszoon Coen terpaksa meninggalkan Jakarta untuk meminta bantuan pasukan VOC di Kepulauan Maluku. Selama peperangan pihak VOC mendapatkan keuntungan karena orang-orang Banten, orangorang Jakarta, dan Inggris tidak bersatu. Perang tersebut dimenangkan oleh pihak VOC atau Kompeni Belanda. VOC atau Kompeni Belanda telah menguasai Jayakarta sepenuhnya yang dijadikan sebagai pusat kekuatan VOC. Jan Pieterszoon Coen menghendaki agar daerah yang direbutnya menjadi sebuah kota Belanda. Jan Pieterszoon Coen menamakan kota itu "Nieuw Hoorn" artinya kota Hoorn Baru. Jan Pieterszoon Coen dilahirkan di kota Hoorn di negeri Belanda pada tahun 1587. Jadi, Jan Pieterszoon Coen hendak menamakan tempat yang direbutnya itu menurut kota kelahirannya dan menamakan kota itu Nieuw Hoorn (Sagimun, 1988:64.

\section{METODE}

Penulisan ini menggunakan metode sejarah dengan melakukan tahapan heuristik, kritik, interpretasi, dan historiografi (Gottschalk, 1985:57) melalui kajian Pustaka yang berhubungan erat dengan Materi Pembahasan. Heuristik adalah metode untuk mencari, mengidentifikasikan dan menemukan sumbersumber Sejarah. Pencaharian ini dilakukan bahwa sumber sejarah merupakan jejak-jejak yang masih dapat diperoleh untuk menelusuri kembali sebuah kejadian sejarah. Sejarah sebagai kejadian 
tidak dapat dimunculkan kembali, tetapi sejarah sebagai kisah/cerita dari kejadian yang dimaksudkan dapat direkonstruksi melalui jejak yang ditinggalkannya. Sumber sejarah dibagi dua berdasar bentuknya Sumber tertulis dan tidak tertulis. Sumber tertulis berupa dokumendokumen, prasasti, catatan perjalanan. Sumber tidak tertulis adalah sumber lisan yaitu pelaku yang terlibat dalam sebuah peristiwa sejarah.

Tahap Kritik merupakan tahap berikutnya setelah heuristik. Tahap kritik ini menjadi tahap seleksi terhadap sumber-sumber tersebut untuk menilai tingkat validitasnya. Tingkat validitas disini adalah otientifikasi (keaslian) sumber, kualifikasi data dalam sumber, dan originalitas sumber serta data dalam sumber. Dari tahap kritik lalu menuju tahap interpretasi. Dalam tahap ini dilakukan penafsiran terhadap data yang telah terseleksi, melalui analisis dan sintesis. Analisis adalah menguraikan sekian data yang ada dan kemudian mencari hubungan dari data-data tersebut melalui sintesis. Untuk mengontrol tingkat objektifitas penafsiran maka digunakan teori serta konsep ilmu-ilmu sosial sehingga hasil penafsiran tidak terjebak dalam sudut pandang subjektif melainkan sebesar-besarnya kepada objektifitas (Kartodirdjo, 1992:24).

Langkah terakhir adalah Historiografi (penulisan sejarah) yaitu mengaktualisasikan hasil penafsiran ke dalam bentuk tulisan. Dalam historiografie diharapkan adanya aspek seni didalam membahasakan hasil penafsiran tersebut. Aspek seni disini tidak dimaksudkan untuk membawa penafsiran/eksplanasi menjadi subjektif atau sekedar bercerita saja tetapi memberi nilai art, karakter, sehingga tulisan sejarah menjadi tulisan yang hidup, tidak kering, karena keberhasilan sebuah historiografie modern di tandai dari kemampuan tulisan itu menghidupkan kembali suatu kejadian sejarah tanpa meninggalkan aspek kritis dan objektifitasnya (Kuntowijoyo, 2004:35).

\section{HASIL DAN PEMBAHASAN}

\section{Penetapan Batavia Sebagai Markas Besar VOC di Sebelah Barat Pantai Utara Jawa}

Sebelum kedatangan VOC ke Nusantara, sebenarnya sudah terjadi suatu perdagangan internasional dengan sistem terbuka yaitu peraturan jual-bel, proses penawaran, penentuan harga, kesemuanya telah mengikuti pola atau sistem yang berlaku. Rempah-rempah tetap menempati sebagai prioritas komoditi utama tetapi tidak terpisah dengan perdagangan beras, lada, kain, dan komoditi lainnya.

Dalam jaringan transaksi dan transportasi komoditi-komoditi tersebut, dengan teknologi navigasi dari zaman itu maka dua basis pemusatan perdagangan dan pelayaran ternyata mempunyai fungsi yang sangat strategis sekali. Garis Malaka-Maluku memang secara struktural merupakan sistem yang berfungsi secara optimal. Tumbuhlah dalam sistem itu subsistem-subsistem dengan pusat-pusat kecil sebagai pendukung dan komplemennya. Dalam usahanya VOC berusaha menduduki Maluku dahulu dan Malaka kemudian serta alternatif lain sebagai pengganti Malaka adalah Batavia. Dari semula VOC kesulitan menghadapi menerobos sistem perdagangan yang berlaku. Dengan kontrak-kontrak hendak diperoleh monopoli namun selama tidak ada dukungan kekuatan politik, tidak dapat berjalan pelaksanaannya. Di kalangan VOC sendiri banyak yang menentang penggunaan kekerasan (Kartodirdjo, 1987:73).

Usaha yang dilakukan VOC adalah mengalihkan kegiatan perdagangan komoditi di Asia (Haalhandel) yaitu perdagangan tidak hanya di komoditi rempah-rempah saja tetapi ke komoditi lain seperti beras, kain, dan lada. Selain itu VOC mencoba menarik perdagangan pribumi dan bangsa Asia ke pusat-pusat yang dikuasainya, seperti Batavia dan Ambon, dengan tujuan menarik pajak dam keuntungan lainnya.

Kemenangan Belanda atas Maluku dan Nusa Tenggara (1613) dan menjelang penyerahan Malaka (1614), membuat kekuasaan Inggris hanya memilki satu loji di Banten, sehingga hanya ada tiga kekuasaan yang perlu di hadapi yaitu Makassar, Aceh, dan Mataram. Ketiga kekuasaan itu juga leluasa menjalankan konsolidasinya dan ekspansinya, walaupun konfrontasi tidak dapat dihindari seperti serangan Batavia pada tahun 1627-1628.

Banten yang basis terdekat dengan VOC di Batavia segera mengalami kemunduran yang disebabkan politk monopoli VOC. Hubungan perdagangan antara Banten dan Malaka sebelumnya sangat baik, rempah-rempah dan lada diambil di Banten dan pakaian dijual di tempat itu oleh Portugis. Namun sewaktu Ambon dan Banda diblokade oleh Belanda, perdagangan rempah-rempah menyusut sekali sedangkan 
permintaan akan bahan pakaian sangat terbatas. Sedangkan perdagangan Indonesia bagain barat berpusat di Aceh, sedang monopoli rempahrempah yang semakin ketat memindahkan pusat pemasaran rempah-rempah di Makassar, perdagangan bahan pakaian dari Gujarat menyusut sekali karena rakyat mulai menenun sendiri (Kartodirdjo, 1987:77)

Penetrasi VOC dalam jaringan perdagangan Nusantara bagian pertama abad XVII menghadapi cukup banyak persaingan, baik pedagang dari dari Nusantara hingga pedagang luar Nusantara, seperti : Gujarat, Keling, Benggali, dan Cina. Komoditi yang mereka kuasai ternyata mempunyai nilai tukar tinggi di Indonesia maka haanhandel ternyata sangat menguntungkan, sering melebihi perdagangan rempah-rempahnya. Kedua jenis perdagangan tersebut terjalin erat satu sama lain sehingga politik monopoli VOC dalam rempah-rempah mau tidak mau diperluas mencakup komoditikomoditi dari perdagangan Asia (Kartodirdjo, 1987:78).

Persaingan yang cukup sengit dan ketat dalam aktivitas pelayaran dan perdagangan di Nusantara pada paruh pertama abad ke-17, membuat pemimpin VOC di Maluku berencana untuk menetapkan kebijakan yang besar dan cukup strategis bagi perkmbangan VOC. Kebijakan tersbut adalah memindahkan pusat dan markas dagang VOC, dari wilayah Timur menuju wilayah Barat. Rencana memindahkan pangkalan dan pusat dagang VOC dari Maluku menuju pulau Jawa, dan kemudian pilihan dijatuhkan ke wilayah Batavia, sebuah wilayah disebelah barat pesisir pantai utara Jawa.

Sebelum membuat keputusan pemindahan Markas besar VOC dari Maluku ke Batavia. Pasti Jan Pieterszoon Coen telah memikirkan secara matang apa yang akan dilakukannya. Karena ini tidak hanya berbicara tentang perdagangan atau pun keuntungan secara materi tetapi dia ingin mengembangkan emporium itu menjadi imperium. Di mana kekuasaan VOC tidak hanya sebatas perdagangan tetapi juga kekuasaan dan sebagai pelopor pertama kekuasaaan di atas kerajaan-kerajaan Nusantara yang sebelumnya telah berkuasa di Nusantara. Alasan pertama yang membuat Jan Pieterszoon Coen memilih Batavia adalah Maluku walaupun sebagai pusat produksi rempah-rempah tapi lambat laun komoditas yang populer seperti Cengkih dan Pala mengalami penurunan atau yang di sebut sebagai mono produksi sedangkan di Pulau Jawa Sendiri selain daerahnya subur sebagai pertanian. Di Jawa terdapat komoditas beras yang tidak kalah pentingnya dengan komoditas Cengkih dan Pala. Tanaman yang bisa ditanam di Jawa tidak hanya beras tetapi juga berkembang yaitu teh, kopi dan gula. Pada periode-periode selanjutnya komoditi ini juga merupakan komoditi utama bagi perdagangan VOC. Beragam komoditas ini disebut multi comodity. Juga di Pulau Jawa banyak sekali pedagang-pedagang Islam yang melakukan perdagangan internasional di mana jika tumbuh suatu lokasi pertumbuhan kegiatan perdagangan di pelabuhan-pelabuhan maka dengan sendirinya terjadi transaksi perdagangan internasional.

Keadaan laut dan angin juga mendukung perpindahan Markas besar VOC tersebut. Kalau saya bisa jelaskan, keadaan laut di sekitar Laut Jawa adalah laut dangkal berbeda sekali dengan keadaan di Laut Arafuru yaitu laut dalam. Keadaan ini juga mempengaruhi pelayaran terutama keadaan kapal-kapal VOC dalam mengangkut barang komoditi di lautan Nusantara. Karena kapal-kapal tersebut bukan hanya sebagai alat pengangkut tetapi ada juga biaya perawatan dari kapal-kapal tersebut. Yang sebagian besar perawatan kapal-kapal VOC dilakukan di Pulau Onrust.

Walaupun VOC memiliki faktorai di Banten sejak 1603 serta perdagangannya ramai tetapi kondisi temapat itu tidak menguntungkan. Pertama, keadaan keamanan sangat menyedihkan, banyak terjadi pencurian, perampok, dan pembunuhan. Kedua, kehadiran Inggris dan Portugis di tempat itu menimbulkan hubungan politik yang kompleks sehingga sering terjadi bentrokan. Gubernur pertama VOC 1609 Pieter Both berusaha melaksanakan rencana konsentrasi pemerintahan VOC, dengan minta izin dari Pangeran Jakarta untuk membangun suatu benteng dengan yurisdiksi sendiri dan bebas dari bea cukai. Persetujuan dari Heren XVII tertunda-tunda saja oleh karena pertimbangan yang pokok sekali bahwa pendirian benteng di Jakarta itu tidak menimbulkan permusuhan dari pihak Banten (Kartodirdjo, 1987:156).

Pendirian emporium di Jakarta oleh VOC perlu diterangkan dengan latar belakang percaturan politik yang berkaitan dengan hubungan multilateral antara kerajaan-kerajaan dan badan- 
badan perdagangan asing. Antagonisme antara Banten dan Mataram selama bagian awal abad XVII sangat kuat sehingga tidak terjadi pendekatan maupun aliansi. Keadaan ini justru menguntungkan pihak VOC sebagai lawan mereka.

Status Vasal bagi Jakarta terhadap Banten membuat Jakarta punya kewenangan sendiri untuk mengadakan kerjasama kontrak sendiri dengan kompeni atau badan perdagangan asing. Dalam diri Pangeran Jakarta ada rasa iri atas kemajuan Banten sehingga dia mengizinkan untuk VOC mendirikan loji di wilayah Jakarta, supaya daerah dia menjadi ramai dan mendapatkan keuntungan. Makanya pedagang Inggris juga boleh mendirikan loji di sana. Untuk menjaga prinsip perdagangan terbuka, maka dia tidak menginginkan terjadinya persaingan dan dominasi antar pedagang asing, maka dia tidak mengizinkan VOC mendirikan Benteng. Padahal Jan Pieterszoon Coen berpikir jika membangun benteng maka tidak hanya melindungi perdagangannya tetapi juga menjadi basis politik utnutk memepertahankan kedudukananya dalam menghadapi keadaan darurat atau krisis politik.

Dengan adanya Inggris di Banten menyebabkan VOC harus mencari lokasi baru untuk kantor pusat. Karena di Banten sering terjadi insiden antara anak buah Kompeni dan orang Inggris. Pada tahun 1617 dua kapal Inggris disita oleh VOC di Maluku dimana perdagangan rempahrempah ditutup bagi bangsa Inggris. Pendirian loji Inggris yang terletak di seberang menyebrang sungai Ciliwung merupakan "duri di mata" Kompeni (Kartodirdjo, 1987:158).

Dari alasan-alasan inilah Jan Pieterszoon Coen telah berpikir jauh ke depan. Beliau ingin bukan hanya mendirikan emporium dalam hal perdagangan tetapi juga ingin memperkuat kedudukan Batavia. Pendirian emporium yaitu dari hanya berupa loji lalu dia minta didirikan benteng dan lama-kelamaan menjadi Castil Batavia dan akhirnya menjadi Stad Batavia. Dari situlah Jan Pieterszoon Coen berpikir bukan hanya ingin menguasai perdagangan tetapi sebagai peletak dasar kekuasaan yang ada di Batavia. Perubahan dari emporium menjadi imperium yaitu bahwa kekuasaan VOC bukan hanya memonopoli perdagangan saja tetapi juga lama kelamaan ingin menguasai raja-raja di Nusantara. Secara tidak langsung Jan Pieterszoon Coen seperti mendirikan Negara baru di wilayah
Nusantara walaupun masih di bawah pemerintahan Kerajaan Belanda. Ini terbukti dengan pengahancuran sistem perdagangan pelabuhan-pelabuhan yang ada di Jawa dan Blokade terhadap pelabuhan yang ada di Banten maupun di Makassar. VOC datang ke Nusantara bukan hanya untuk sekedar berdagang tetapi memonopoli semua perdagangan di Nusantara dan lambat laun menguasai kerajaan-kerajaan yang ada di Nusantara.

\section{Kebijakan Politik dan Ekonomi JP. Coen Dalam Memperkuat Posisi Batavia \\ 1. Memperbanyak Aktivitas Pelayaran dan Perdagangan di Pelabuhan Sunda Kalapa}

Salah satu prasasti Purnawarwan raja Tarumanagara, yang ditemukan di desa Tugu, Jakarta Utara, mengisyaratkan tentang adanya "Kota" di daerah pantai utara Jawa Barat sekitar perairan Teluk Jakarta (Poerbatjaraka, 1952, Noorduyn \& Verstappen. 1972: 298-307). Beritaberita Cina yang berasal dari masa pertengahan abad V sampai abad VII telah menyebutkan pula adanya hubungan antara Cina dengan kerajaankerajaan di Jawa Barat, yaitu Ho-lo-t'o atau Holo-tan, dan To-lo-mo (Taruma) (Wolters, 1967: 354). Berdasarkan berita Cina tersebut, diduga di daerah pantai utara Jawa Barat telah terdapat tempat-tempat yang menjadi pusat pelayaran dan perdagangan, salah satunya adalah Sunda Kalapa. Letak geografisnya yang sangat strategis di daerah dekat jalur pelayaran kawasan barat (India) dan kawasan timur (Cina), menyebabkan beberapa tempat di daerah pantai utara Jawa Barat telah berkembang dengan pesat menjadi kota-kota pelabuhan yang besar dan penting serta ikut berperan dalam perdagangan di Jalur Sutera.

Sumber utama mengenai pelabuhan Sunda Kalapa terutama diperoleh dari sumber-sumber Eropa, khususnya sumber Portugis. Sumber Portugis ini yaitu laporan kejadian Tome Pires yang ditulis di Malaka dan India tahun 15121515, berjudul Suma Oriental. Berisi pelaporan atau kisah perjalanan ke Asia, dari daerah sekitar Laut Merah sampai ke Jepang. Pada tahun 1513 Tome Pires sampai di Jawa dan menyusuri pantai utara, serta singgah di beberapa pelabuhan. Uraian mengenai Jawa (ylha de Jaoa) Tome Pires memulainya dengan uraian tentang Sunda (Cumda). Uraiannya sangat rinci, meliputi keadaan daerah, kota-kota dan pelabuhan, perdagangan dan hasil bumi, kehidupan masyarakat dan pemerintahan. Berdasarkan 
pemberitaan Tome Pires ini kita mengetahui bahwa Kerajaan Sunda beribukota Dayo (Dayeuh) yang terletak di pedalaman, dan dapat ditempuh melalui perjalanan selama dua hari dari pelabuhan Calapa. Tome Pires menyebutkan pula pada waktu itu kerajaan Sunda telah memiliki enam buah pelabuhan, yaitu: Bamtam (Banten), Pomdam (Pontang), Chegujde (Cigede), Tamgaram (Tanggerang), Calapa (Kalapa), dan Chemano (Cimanuk). Tome Pires melukiskan kota pelabuhan Kalapa sebagai pelabuhan utama yang sangat megah dan paling baik diantara pelabuhan-pelabuhan yang lain. Pelabuhan ini dikelola dengan baik oleh suatu pemerintahan lokal di bawah kekuasaan seorang Syahbandar (Cortessao, 1944: 166).

Pada masa Kerajaan Sunda pelabuhan Sunda Kalapa sudah menjadi pelabuhan utama. Ibukota kerajaan ini, Pakuan Pajajaran, terletak di Batutulis (Bogor) dan pada masa itu dapat dicapai dalam dua hari perjalanan dengan menyusuri Ciliwung. Sunda Kalapa dikunjungi kapal-kapal dari Palembang, Tanjungpura, Malaka, Makassar, dan Madura, bahkan oleh pedagang-pedagang dari India, Tiongkok Selatan, dan Kepulauan Ryuku (kini Jepang). Sunda Kalapa mengekspor antara lain lada, pala, beras, dan juga emas, seperti juga cula badak ke Tiongkok (Heuken SJ, 1997: 22).

Pelabuhan Sunda Kalapa merupakan pelabuhan yang menakjubkan dan yang terpenting di antara pelabuhan lainnya. Perjalanan ke Pelabuhan Sunda Kalapa memakan waktu dua hari dari Kota Dayo (Pakuan Pajajaran) di masa Sang Raja Selalu Tinggal. Karena itulah, pelabuhan ini dianggap yang terpenting. Pelabuhan ini hampir menyatu dengan Negeri Jawa, namun Cimanuk memisahkan mereka. Perjalanan dari Cimanuk ke pelabuhan ini memakan waktu sehari semalam dengan angin ynag baik. Komoditas dagang dari seluruh penjuru kerajaan di bawa ke pelabuhan ini. Tempat ini dikelola dengan baik; dengan adanya hakim, peradilan, dan juru tulis. Dikabarkan bahwa [peraturan] di kota ini telah [dicantumkan] dalam tulisan, [sebagai contoh] seseorang yang melakukan perbuatan A akan dikenakan B dan seterusnya sesuai hukum kerajaan. Banyak Jung yang merapat ke pelabuhan ini (Pires, 2014:242)

Menjelang masa akhir kerajaan Sunda terjadi peristiwa penting yaitu perjanjian antara pihak Portugis dan Sunda. Perjanjian ini ditandatangani pada tanggal 21 Agustus 1522. Isinya ialah kesepakatan pihak Portugis untuk membantu kerajaan Sunda jika sewaktu-waktu Sunda diserang oleh orang-orang Islam. Sebaliknya sebagai imbalan pihak Sunda menjanjikan Portugis mendirikan benteng di Bandar Banten, dan diberi hak untuk memperoleh lada sebanyak 350 kuintal setiap tahunnya. Saksi dari pihak Sunda adalah 'Padam Tumungo, Ssamgydepati et Bemgar, yakni Paduka Tumenggung, Sang Adipati dan Syahbandar dari Sunda Kalapa dan dari pihak Portugis delapan orang. Perjanjian itu (tidak ditandatangani oleh pihak Sunda, tetapi) disahkan menurut adat dengan mengadakan selamatan (Heuken SJ, 1999:47).

Walaupun sudah ditetapkan bahwa benteng Portugis berdasarkan perjanjian tersebut akan dibangun di Banten tetapi kemudian mereka memilih Kalapa sebagai tempat yang cocok untuk pendirian benteng itu. Sehubungan dengan perjanjian antara Portugis dan kerajaan Sunda pada tahun 1522, seorang ahli sejarah dari Perancis Claude Guillot, telah menulis sebuah artikel berjudul "Le necessaire relecture de I'accord Iuso-sundanais de 1522", yang dimuat dalam majalah Archipel, 42, 1991:53-77. Di dalam artikelnya ini Guillot mengemukakan sanggahannya terhadap anggapan para ahli sejarah selama ini, yaitu bahwa perjanjian 1522 antara Portugis dan Sunda itu tidak diadakan di Sunda Kalapa, dan tugu padrao tidak dipancangkan di Sunda Kalapa. Ke-empat alasan Guillot tersebut mendapat sanggahan dari Pater Adolf Heuken, berdasarkan telaah-ulang atas dokumen-dokumen Portugis yang berkaitan dengan masalah Perjanjian Sunda - Portugis tahun 1522. Untuk melengkapi sanggahannya yang Pater Adolf Heuken melakukan pula penelaahan terhadap peta-peta kuno Portugis maupun Belanda dari masa sekitar abad XVI (Djafar, 2008: 4-7).

Dengan tercapainya persetujuan antara Portugis dengan kerajaan Sunda, berarti Portugis berkesempatan meluaskan kekuasaannya sampai pulau Jawa. Hal itu akan merugikan monopoli dagang Demak di pelabuhan pantai utara Jawa dan membahayakan kesultanan Demak. Oleh karena itu, maka sebelum Portugis berhasil mendirikan benteng di pelabuhan Sunda, yaitu Kalapa, pelabuhan itu harus direbut lebih dahulu oleh pasukan bersenjata Demak (Atja, 1986: 5859). Langkah awal yang dilakukan VOC untuk membangun jaringan perdagangannya adalah mengangkat Jan Pieterszoon Coen dari kota 
Hoorn Belanda sebagai Kepala Tata Buku (Akuntan) VOC yang diberi wewenang atas kantor dagang VOC di Banten dan Jayakarta. J.P. Coen yang menaruh perhatian besar terhadap Jayakarta dan berusaha untuk menjadikan tempat ini sebagai pusat kegiatan perdagangan VOC di pulau Jawa (Lubis dkk., 2003: 261).

Potensi dan nilai ekonomis yang dimiliki oleh wilayah Batavia, ternyata tidak hanya dilihat oleh VOC saja, akan tetapi pihak kongsi dagang Inggris (EIC) juga melihat potensi tersebut. J.P.Coen sebagai pimpinan VOC saat itu merumuskan dua langkah utama agar dapat menguasai dan mengamankan posisi mereka di Batavia, dari ancaman EIC dan penguasa Batavia saat itu (Pangeran Wijayakrama). Langkah pertama yang dilakukan J.P.Coen adalah mendapatkan izin dar penguasa Batavia untuk mendirikan kantor dagang di wilayah Batavia, kemudian langkah berikutnya ialah mendirikan benteng sebagai pertahanan militer untuk mengamankan segala asset yang dimiliki oleh VOC di Batavia. Keberadaan benteng inilah yang kelak menjadi awal keberatan dari Pangeran Wijayakrama selaku penguasa Batavia, dan memunculkan ketegangan antara VOC dengan Pangeran Wijayakrama (Lubis dkk, 2003: 262263).

\section{Merevitalisasi Pulau-Pulau di Utara Batavia (Bagi Kepentingan Perdagangan dan Militer)}

Pulau-pulau yang berada dalam wilayah administratif Kepulauan Seribu memiliki peranan yang besar dalam kegiatan perdagangan VOC. Pulau yang paling penting dalam membantu kegiatan perdagangan VOC adalah Pulau Kapal (Onrust).

Di sekitar pulau-pulau ini Jan Pieterszoon Coen menyusun gelar armadanya pada tahun 1618 untuk menahan serangan armada Inggris di bawah komando Sir Thomas Dale. Beberapa tahun sebelum Batavia didirikan, Pulau Onrust telah dipergunakan untuk memperbaiki kapalkapal Kompeni (1615). Sesudah beberapa bulan berlayar dari Eropa ke Jawa, atau dari India, Jepang dan Ambon ke Batavia kapal-kapal perlu di tarik ke pantai, dimiringkan, dan ditambal dan papan-papan yang tidak lagi kuat diganti. Dalam rumah sakit kecil awak kapal yang jatuh sakit dirawat (Heuken, 1997:301).

Setelah periode pergantian gubernur jenderal VOC sekitar tahun pertengahan abad 17 banyak meriam-meriam yang ditempatkan di panatai dan sebuah kubu dibangun. Tahun 1671 diganti dengan Benteng Bekhuis. Artileri ditempatkan di pulau-pulau sekitarnya untuk melindungi kapalkapal yang sedang diperbaiki maupun muatan kapal yang berharga terhadap serangan kapal Prancis di bawah Komando Francois Caron dan perompak-perompak lainnya. Daerah di dalam tembok banyak dipenuhi dengan macam-macam gedung, sehingga praktis tidka mungkin membela dermaga ini. Mudah dimengerti bahwa Pulau Onrust sangant penting bagi perdagangan VOC yang hampir sepenuhnya mengandalkan kapal layar. Kesan yang diperoleh tempat ini memang kecil tapi sangat ramai dan sibuk.

Peranan besar dari Pulau Onrust juga pernah dibicarakan oleh James Cook (Inggris) yang memuji tukang-tukang kayu yang terampil yang bekerja di Onrust. Kapal Endeavor milik James Cook pernah diperbaiki pada saat perjalanan mengelilingi dunia tahun 1770. Di Pulau Onrust juga terdapat sebuah gereja kecil (1772), yang fondasinya masih dapat ditunjukan oleh penjaga. Dapat dilihat pula tempat bekas tiga derek, dua kilang gergaji serta sebuah gudang mesiu meriam. Beberapa gudang besar menyimpan bahan pemberat, yang dperlukan oleh kapal-kapl layar seperti contoh kayu, tembaga dari Jepang, sendawa dan timah.

Pulau-pulau lain di sekitar Onrust yang memiliki peranan dan sejarah yang sama yaitu Pulau Kahyangan (Cipier). Dahulu ada sebuah dermaga panjang dari Pulau Kahyangan (Cipier) ke arah Pulau Onrust. Di Pulau Kahyangan (Cipier) ini terdapat juga fondasi sebuah benteng bundar besar dan empat meriam kapal yang digali dari pasir pantainya. Di pulau itu pada dahulu kala disimpan barang muatan kapal yang sedang diperbaiki di Onrust. Di Pulau itu juga terdapat banyak meriam kuno. Sisa tembok-tembok di pulau ini termasuk bekas bangunan sebuah penjara dari masa yang lampau. Di sana terdapat sisa-sisa sebuah sel, yang lazimnya digunakan untuk melaksanakan hukuman mati. Pulau ini memiliki sebuah sumur alam yang manis airnya (Heuken, 1997:307).

Pulau Kelor atau Onrust Inggris memiliki reruntuhan sebuah benteng bundar dengan tembok yang kuat. Pulau yang disebut juga "Kerkop", terdapat banyak makam yang semakin dikikis oleh ombak, sehingga tulang belulang terangkat dan berserakan. Pulau Bidadari atau 
Pulau Sakit (Purmerend) terdapat sisa sebuah menara besar bundar yang kuat. Pintu masuk di lantai dua dan bekas-bekas kolong besar, yang digunakan sebagai gudang mesiu dan dapat dimasuki. Menara yang besar ini dibuat sekiar abad ke-19. Di atas menara ditempatkan meriammeriam. Kalau sekarang puing menar ini dikelilingi taman yang indah. Tahun 1679 pulau ini pernah menjadi Rumah Sakit bagi para penderita Kusta yang sebelumnya rumah sakit tersebut berada di Angke. Dan setelah beratusratus tahun Pulau Bidadari di sulap menjadi tempat wisata, walaupun masih ada beberapa nisan di sana tapi banyak tulang dan kerangka yang dikumpulkan dan di bawa ke Pulau Kelor (Heuken, 1997:307).

Pulau Damar atau Pulau Edam pada tahun 1881 masih terdapat mercusuar yang bisa terlihat dari jauh bahkan dari Bandar Udara Soekarno Hatta Cengkareng. Fungsi pulau ini adalah sebagai stasiun radar untuk memandu pesawat terbang ynag menuju Bandar Udara Kemayoran. Saat Gibernur Jendral Campuijs mendirikan rumah bagus bertingkat dua. Pulau Edam dijadikan tempat peristirahatan karena hobi dari Campuijs yang menanam bonsai di antara batu-batu wada, meamsang jembatan-jembatan kecil dan air terjun. Sehingga orang-orang pernah mengaanngap Pulau Edam sebagai salah satu pulau yang menyenangkan di dunia (1682). Setelah berganti gubernur jendral Van Riebeck (1705), fungsi Pulau Edam lebih kepada bengekel pembuatan tambang dan penggergajian kayu, tempat para tawanan menjalani kerja paksa (Heuken, 1997:309).

\section{Kebijakan Politik Pintu Terbuka Bagi Pedagang dan Pendatang Tionghoa}

Pada awal abad ke-17, sebelum kolonial Belanda datang ke Nusantara, bangsa Indones dengan Cina telah terlibat dalam hubungan perdagangan yang dimulai saat dinasti Han (206SM-220M). Pada masa ini, Tiongkok telah membuka jalur perdagangan dengan negaranegar yang ada di kawasan Asia Tenggara. Dalam hal ini, Jawa dan Sumatera termasuk dalam jalur pelayaran tersebut. Lambat laun, banyak penduduk Cina yang bermigrasi ke kepulauan Nusantara, karena daerah Nusantara sangat subur dibandingkan dengan negeri Tiongkok yang tandus dan kerap terjadi peperangan dan bencana alam.

Sebagian besar imigran Cina adalah laki-laki dan mereka tidak membawa istri dari negeri asalnya, maka mereka pun menikah dengan wanita setempat. Imigran Cina ini kemudian bermukim sampai beberapa generasi dan tidak pernah kembali ke negeri asal mereka. Oleh karena itu, muncullah etnis Tionghoa peranakan yang kemudian merasa menjadi orang Indonesia, sebab meraka lahir, besar, bekerja dan meninggal di bumi Nusantara, bahkan sebagian besar mereka tidak bisa berbahasa Cina, serta mengganggap Nusantara sebagai tanah airnya sendiri.

Hubungan antara kedua bangsa semakin erat semenjak adanya kunjungan Panglima Cheng Ho ke Nusantara pada abad ke-15. Pada saat itu Cheng Ho menegmban misi dari Kaisar Cheng Zhu untuk menjalankan politik kerukunan dan persahabatan dengan bangsa-bangsa asing, termasuk Nusantara. Pada saat kedatangan Panglima Cheng Ho yang pertama, sudah banyak terdapat warga etnis Cina di Pulau jawa, Sumatra, dan kaliamnatan. Pada akhir masa diansti Ming (1368-1644) dan awal dinasti Ch'ing (16441911) jumlah imigran Cina yang datang ke Nusantara semakin bertambah. Hal ini disebabkan adanya penyerangan bangsa Manchu terhadap dinasti Ming, sehingga banayak penduduk Cina yang bermigrasi menghindari peperangan (Wijayakusuma, 2005:8).

Imigrasi orang Cina pertama secara alami berasal dari Hokkien Provinsi Hukien di Cina Selatan dan mendarat di Jawa dari Pelabuahan kota Amoy. Para imigran berbicara dialek Hokien dan bahasanya, tata cara serta tradisi budaya yang lama kelamaan menyatu dengan tradisi penduduk lokal. Pengaruh budaya Hokkien terdapat pada budaya Betawi yang diidentifikasikan dalam "Bahasa Betawi" (bahasa ibu dari oarang-orang Jakarta) terutama dalam hal kata-kata yang

beberapa tingkatan bisa dikenali dalam budaya peranakan di Jawa (Leo, 1973: 33).

Pemukiman Cina secara resmi berada di Batavia, dan terletak di timur sungai Ciliwung dan secara administrasi dipimpin oleh seorang Kapiten yaitu Nakhkoda Watting. Pada bualan Januari 1611 perjanjian dibuat anatara Jacques l'Hermite dengan Pangeran Ariawijaya Krama pembelian mengenai lahan yang mana berdekatan dengan pemukiman Cina di Jakarta. Harga disepakati 3000 Gulden, setelah VOC mulai membangun loji di muara sungai Ciliwung. Dari masa inilah dimulai penetrasi VOC dan dominasi yang menjadi tidak bisa dihindari bagian dari sejarah 
Indonesia dan kota Batavia. Sebelum pendaratan pertama di Banten pada bulan Juni 1596, Cina telah memiliki posisi dominan dalam perdagangan lada dan bermain dalam pada aturan besar jaringan perdagangan pasar Asia yang sedang berkembang di wilayah ini.

Pengalaman dalam VOC sejak dia berusia 22 tahun, Gubernur Jenderal Jan Pieterszoon Coen merencanakan membangun kekuatan penuh kekuatan VOC di wilayah timur seperti Portugis yang telah melakukannya di Goa, Malaka, dan Makau. Coen, pria berwawasan dan memliki pandangan ke depan yang tajam, melihat bahwa, tetangganya yaitu pelabuhan Banten berkembang. Pengalamannya yang luas di Timur, meyakinkanya bahwa kemakmuran kota merupakan bagian dari tata niaga dan industri yang dilakukan orang-orang Cina. Lagipula, ide Coen untuk membangun di timur tidak disetujui oleh Heeren 17, dari surat-suratnya yang permintaanya tidak pernah dibalas. Tuan Coen mengatakan bahwa "daer is geen volck die ons beter dan Chinesesen dienen" (Tidak ada orang lain yang bisa melayani lebih baik dibanding orang-orang Cina) (Haan, 1922:10).

Didorong oleh perhatian untuk membangun Batavia, dimana beberapa tahun kemudian adalah kejayaan diketahui sebagai Koningin van het oosten (Ratu dari Timur), Coen mengajak orangorang Cina dari Banten dan penduduk pinggir pantai seperti Cirebon dan Jepara untuk pindah ke Batavia. Bahkan itu menandakan bahwa dia memerintahkan tentaranya untuk menangkap orang-orang Cina. Awalnya upaya penculikan di Tiongkok berkedok perdagangan. Oleh karena upaya perdagangan tidak berhasil, maka dilakukanlah upaya penculikan penduduk di tahun 1622 untuk dijadikan budak. Dibawah perintah Komandan Cornelis Reyerz, VOC mulai melakukan penculikan di berbagai kepulauan Tiongkok, salah satunya di Pulau Peng Hu. Kurang lebih penduduk Peng $\mathrm{Hu}$ diculikuntuk dipekerjakan sebagai budak di batavia dan nusantara lainnya. Mereka sering mendapat perlakuan yang sangat menyedihkan dan tidak berperikemanusiaan, sehingga mengakibatkan lebih dari setengah jumlah mereka meninggal dunia dan hanya tersisa 571 orang. Dalam perjalanan menuju Batavia, 473 orang meninggal dunia dan hanya sedikit saja yang sampai ke Batavia dan pada akhirnya hanya tersisa 33 orang (Vermeulen, 1938:9). Melihat maraknya perdagangan di Batvia, VOC kemudian berencana untuk membangunnya hingga menjadi sentra perdagangan dan pemukiman bagi para pejabat VOC. Untuk merealisasikan hal itu, VOC banyak memerlukan budak. Sebagian besar budak diambil dari Bengali, arrakan, Malabar, Koromandel, bahkan Tiongkok. Para budak ini, umumnya memiliki keterampilan seperti koki, tukang kayu, tukang batu, penjahit, tukang kode, dan lainnya. Kehidupan mereka sangat memprihatikan karena mereka kerap dianiaya. Oleh karena itu, banyak budak yang melarikan diri ke hutan (Hardi, 1987:77-78).

Saat kota mengalami pertumbuhan, orang-orang Cina ikut membangun Batavia seperti tukang kebun, petani beras, penjual ikan, dam juga menjadi pemahat, tukang ledeng, tukang kayu, pemotong kayu, pemilik toko. Dan mereka juga bekerja di konstruksi bangunan dan kantor-kantor VOC, membangun kanal-kanal (grachten) dan membuat kapal-kapal. Beberapa dari mereka menyelidiki daerah pedalaman disekitarnya, Ommelanden, dan mengolah tanah untuk perkebunan gula serta penyulingan arak. Imigran Cina ada sekitar 300 sampai 400 jiwa di Batavia pada bulan Oktober 1619. Pada bulan Juli 1620, pertumbuhan penduduk imigran Cina meningkat menjadi 800 jiwa. Di tahun 1621 jumlah mereka 2100 jiwa dan tahun 1627 sebanyak 3500 jiwa, tapi tahun 1629 mereka mengalami penurunan menjadi 2000 jiwa (Lohanda, 1996:8).

Warga imigran Cina mulai mengusahakan pendirian pabrik-pabrik penggilingan tebu untuk pembuatan gula. Banyaknya pabrik penggilingan tebu yang berdiri di sepanjang daerah Batavia telah memberikan keuntungan, bukan hanya untuk warga imigran Cina tetapi untuk VOC. Kemajuan usaha ini membuat VOC memghentikan impor gula dari Cina Daratan yang saat itu dianggap memilki harga yang lebih tingi. Pada tahap awal jumlah pekerja rata-rata di setiap pabrik gula mencapai 112 orang tenaga kerja, $40 \%$ adalah waraga imigran Cina yang bertanggung jawab memasak gula dan $60 \%$ adalah tenaga kerja dari warga pribumi, yang bertanggung jawab menanam, menebang, dan menggiling tebu, serta mengangkut bahan dan barang jadi. Melihat maju pesatnya usaha perkebunan tebu dan penggilingan tebu yang dimiliki warga imigran Cina, maka tindakan monopoli VOC semakin meningkat. Pemerintah VOC mengharuskan pemilik pabrik penggilingan tebu untuk menjual gulanya kepada VOC dengan harga relatif rendah. Selain ityu, pungutan bea 
dan pajak kepala terhadap mereka terus dinaikkan, tanpa mengenal perikemanusiaan.

Dapat dikatakan bahwa saat itu masa kejayaan ekonomi warga imigran Cina. Pada wkatu itu tingkat permintaan gula di pasaran Eropa sangat tinggi. Hal ini ditunjang pula oleh adanya perjanjian perdamaian dengan Banten tahun (1683), sehingga mendukung sekali penegmabangan usaha gula. Oleh karena itu, komisaris VOC, meningkatkankan pembeliannyakepada warag imigran Cina yang menjadi pengusaha gula. Banyaknya pabrik gula membutuhkan banyak pekerja sehingga memicu meningkatnya arus migrasi penduduk Cina. Para imigran ini adalah pekerja ilegal. Situasi ini memaksa pemilik usaha penggilangan gula (Chinese Potchias) kerap harus bermurah hati kepada mereka untuk dipekerjakan di penggilingan gula miliknya. Dari sekian banyak imigran Cina yang ilegal tidak sedikit yang menjadi budak. Banyaknya imigran Cina yang datang ke Batavia, membuat VOC menerapkan peraturan bea masuk yang lebih tinggi terhadap mereka. Meningkatnya tekanan peraturan terhadap warga imigran Cina oleh pemerintah pusat tersebut, membuat pejabat-pejabat VOC bertindak korup. Akibatnya, segala sesuatu yang dipandang hanyalah materi semata. Untuk mendapatkannya tak segan mereka melakukan pemerasan (Wijayakusuma, 2005:76)

\section{PENUTUP}

Jan Pieterszoon Coen adalah seorang gubernur jenderal yang memiliki wawasan ke depan (Visioner). Ini bisa dibuktikan bahwa penguasaan terhadap Batavia memberikan dampak positif bagi perdagangan VOC. Tuan Coen bukan hanya berpikir memindahkan markas besar VOC dari Maluku ke Batavia, tetapi alasan lain Batavia dijadikan pusat perdagangan dengan pendirian loji yang lambat laun menjadi Casteel Batavia membuktikan bukan hanya ingin menguasai perdagangan tetapi kepada kekuasaan dengan membentuk pemerintahan di Batavia. Istilah Emporium yaitu hanya sebagai loji atau tempat gudang penyimpanan barang perdagangan lambat laun berkembang menjadi Imperium. Dari istilah Imperium saja bisa di jelaskan tujuan dari Tuan Coen. Batavia adalah pusat kekuasaan dari VOC yang ada di Nusantara yang juga merupakan perpanjangan tangan dari kekuasaan pemerintahan kerajaan Belanda.
Kecerdasan dan kepiawaian J.P. Coen dalam memilih dan membangun kota Batavia dapat dilihat melalui bagaimana J.P. Coen mengeluarkan tiga kebijakan utama yakni memperbanyak aktivitas perdagangan di pelabuhan Sunda Kalapa, merevitalisasi pulaupulau di utara Batavia dan membangun persekutuan dengan pedagang dan pendatang dari Tionghoa. Secara umum kebijakan tersebut sebagai berikut : Pelabuhan Sunda Kalapa memiliki arti penting karena pelabuhan tersebut sudah ramai dengan perdagangan internasional sebelum kedatangan VOC. Gubernur Jenderal VOC Jan Pieterszoon Coen melihat potensi ini dengan cara mendirikan loji di seberang sungai Ciliwung dengan mendapatkan izin dari Pangeran Jayakarta agar dapat memantau situasi di pelabuhan Sunda Kalapa dan sewaktu-waktu bisa mengadakan penyerangan terhadap Pelabuhan tersebut. Pulau-pulau di sekitar Teluk Jakarta juga memiliki peranan yang penting terutama Pulau Onrust dimana sebagai tempatb bersandarnya kapal-kapl dagang VOC dan juga sebagai tempat perbaikan atau perawatan kapalkapal tersebut (bengkel).

Imigran Cina banyak memilki peranan di Nusantara terutama perkembangan Batavia. Sebelum VOC menguasai Batavia, imigran Cina telah melakukan kegiatan perdagangan dengan pedagang Nusantara. Tetapi setelah kedatangan VOC di Batavia, Coen banyak menggunakan imigran Cina dalam pembangunan Batavia. Banyak dari imigran Cina yang bekerja sebagai tukang kayu, tukang kebun, pemilik toko, pemahat, pemilik perkebunan tebu, penyuling arak, pegawai administrasi, dan yang bernasib kurang baik dijadikan budak oleh orang-orang VOC dalam pembangunan kanal-kanal di Casteel Batavia. Di dalam masyarakat Cina ada seorang yang diangkat menjadi pemimpin dan biasanya berasal dari keluarga kaya, pemimpin ini disebut Kapiten. Kerajinan dan keuletan imigran Cina membuat mereka sebagai salah satu pembangun perekonomian Batavia. Mengenai pertumbuhan Batavia yang masih bergantung kepada imigran Cina, hal ini seperti yang dikemukan oleh Francois Valentijn bahwa apabila tidak ada imigran Cina, Batavia akan menjadi kota yang kehilangan pesonanya. 


\section{DAFTAR RUJUKAN}

Atja, 1986. Carita Purwaka Caruban Nagari: Karya Sastra Sebagai Sumber Pengetahuan Sejarah. Bandung: Proyek Pengembangan Permuseuman Jawa Barat.

Djafar, Hasan. 2008. "Beberapa Masalah Sekitar Kerajaan Sunda dan Sumber Sejarahnya", (Makalah Pada Seminar Revitalisasi Makna dan Khasanah Situs Sindangbarang). Bogor: Dinas Kebudayaan dan Pariwisata, Pemda Kab. Bogor

Han, F. De. 1922. Oud Batavia. Bandung: A.C. Mix \& Co.

Hardi, Lasmidjah. 1987. Jakartaku Jakartamu Jakarta Kita. Jakarta: Yayasan Pecinta Sejarah \& Pemerintah DKI Jakarta.

Heuken, Adolf. 1997. Tempat-Tempat Bersejarah Di Jakarta. Jakarta: Cipta Loka Caraka.

1999. Sumber-Sumber Asli Sejarah Jakarta Jilid 1. Jakarta: Cipta Loka Caraka.

Kartodirdjo, Sartono. 1987. Pengantar Sejarah Indonesia Baru 1500-1900 (Dari Emporium Sampai Imperium) Jilid 1. Jakarta: PT Gramedia.

Leo, Philip. 1973. Chinese Loanwords Spoken by the Inhabitants of the City of Jakarta. Jakarta: LRKN-LIPI.
Lohanda, Mona. 1996. The Kapitan Cina of Batavia 1837-1942: A History of Chinese Establishment in Colonial Society. Jakarta : Djambatan.

Lubis, Nina H., dkk. 2003. Sejarah Tatar Sunda, Jilid 1. Bandung: Lembaga Penelitian Universitas Padjajaran

Noorduyn, J. \& H.TH. Verstappen. 1972. "Purnavarman's River-works Near Tugu". Bijdragen tot de Taal-, Land- en Volkenkunde. 128: 298-307.

Pires, Tome. 2014. Suma Oriental Perjalanan Dari Laut Merah ke Cina \& Buku Francisco Rodrigues (Diterjemahkan oleh Adrian Perkasa dan Anggita Pramesti). Jakarta: Penerbit Ombak.

Sagimun, 1988. Jakarta Dari Tepian Air ke Kota Proklamasi. Jakarta : Pemerintah Daerah Khusus Ibukota Jakarta Dinas Museum \& Jakarta.

Soekanto, 1954. Dari Djajakarta ke Djakarta. Jakarta. Penerbit "Soerangan" Petjenongan 58 Djakarta.

Vermeulen, J.T.1938. De Chineezen te Batavia en de Troebelen van 1740. Leiden : E.Ijdo.

Wijayakusuma, Hembing. 2005. Pembantaian Massal 1740 Tragedi Berdarah Angke. Jakarta: Pustaka Populer Obor.

Wolters, O.W. 1967. Early Indonesian Commerce: A Study of the Origin of Siwijaya. Ithaca/New York: Cornell University 